\title{
Devlet İdaresinde Farklılıkların Yönetimi: Farklılıklar Değerimizdir Kurgusu Üzerine Bir Deneme
}

Management of Diversities in State Administration: A Study on the Suggestion that Diversities are Our Value

\section{Doç. Dr. Konur Alp DEMiR ${ }^{1}$}

Başvuru Tarihi: 03.11.2018

Kabul Tarihi: 17.02.2020

Makale Türü: Derleme

\section{Öz}

Bu çalışmanın temel çıkış noktası "farklılıklar değerimizdir" kurgusunun nasıl ve hangi yollarla toplumun tamamina yayılacağı ve yönetim sistemimizin bu alanda etkili bir biçimde faaliyet gösterebilmesi için nasıl daha iyi bir şekil alması gerektiği sorunsalının tartışılması ihtiyacıdır. Bu sayede farklılıklar ayrışmanın bir unsuru değil, bütünleşmenin bir aracı haline dönüşebileceklerdir. Aynı zamanda farklılıkların iyi bir biçimde yönetilmesi sonucunda idealize edilen toplumsal huzur kurgusu sağlanmış olacaktır. Bu çalışmanın temel amacı bir ideal olarak görülen toplumsal farklılıkların yönetimi olgusunu "farklılıklar değerimizdir" kurgusu üzerinden yeniden tanımlamaktır. Bu amaçla çalışmada yabancı ve yerli literatür kullanılarak ve toplumsal huzurun sağlanması adına girişilen faaliyetler kapsamında toplumsal farklilıklar olgusu ve devlet ile sivil toplum kuruluşları üzerinden farklılıkların yok sayılmadan yönetilebilmesi için yapılması gerekenler vurgulanacaktır. Bu çalışmadan beklenen sonuç Türkiye gibi çok farklı kültürlerin yaşandiğı, farklı inançların bir arada yer aldiğı ve farklı dillerin konuşulduğu bir coğrafyada, farklılıkları bir değer olarak kabul ederek aynı çatı altında yaşatmanın yollarının devletin ve sivil toplum kuruluşlarının ortak çalışmasından geçtiğini vurgulamaktır.

Anahtar Kelimeler: Farklılıkların Yönetimi, Toplumsal Huzur, Çokkültürlülük, Etnik Çeşitlilik, Kültürel Çeşitlilik

\section{Abstract}

The main point of this study is to discuss how to spread the understanding of fiction of "the diversities are our value" and another point is the way in which will spread to all areas of society. The other point is about administration system. The administration system needs to operate effectively but there is a problem and it needs to be discussed how to take shape the administration system for operating it effectively. Thanks to this conception, the diversities will be able to transform

\footnotetext{
1 Tekirdağ Namık Kemal Üniversitesi, İktisadi ve İdari Bilimler Fakültesi, Siyaset Bilimi ve Kamu Yönetimi Bölümü, konuralpdemir@yahoo.com.tr, ORCID: 0000-0003-1199-930X
} 
a means of integration instead of being a component of disintegration. At the same time, as a result of governing the differences ably, idealized social peace will be provided. The main aim of this study is to redefine the phenomenon of managing of social diversities by using the fiction of "the diversities are our value" which seems to be perceived as an ideal. To that end, in this study, ensuring social peace within the scope of the activities which is undertaken on behalf of the phenomenon of managing of social diversities will be highlighted what have to be done to govern the diversities without ignoring by means of state and non-governmental organization. The expected outcome of this study is to highlight to find ways for living together in the context of state and non-governmental organization, population of Turkey in which lives together without ignoring the diversities of religion, different language which is spoken and different cultures in which lived in a geography such as Turkey, instead of being stereotyped the whole society, have to be accepted as a value.

Keywords: Diversity Management, Social Peace, Multiculturalism, Ethnic Diversity, Cultural Diversity

\section{Giriş}

Her insan yaratılış itibarıyla diğer insanlardan farklıdır. Bu farklılık sosyal davranışlara da yansımakta ve her insanı diğer insandan ayrımlı bir konuma getirmektedir. Esas olarak farklılık, toplumsal değişkenleri ve farklı kültürleri toplum içerisinde belirli bir dengede tutma aracıdır. Bir toplum içerisindeki farklılıkların bütünleşmesi her bireyin bir diğerinin kültürüne eklemlenmesi şeklinde gerçekleşmektedir. Bu kapsamda kültür bütünleşmeyi ve gizli kalmış farklılık potansiyelini açığa çıkartmaya yarayan bir araç niteliğindedir (Pless ve Maak, 2004, s. 130).

Yönetim bilimi tarihsel süreç içerisinde insanların yaratılış farklılıklarından dolayı ortaya çıkan değişmeleri incelemiş ve yöneticiler farklılıkları belirli bir dengede tutmaya çalışmışlardır. Yönetimde yaşanan gelişmeler ve klasik yönetim anlayışının yerini modern yaklaşımlara bırakması farklılıkların nasıl daha iyi bir biçimde yönetilebileceği sorunsalı üzerine kurgulanmıştır. Bu kurguyu uygulamaya geçirebilmek için yönetimde "yeni yönetim paradigması”, “örgütsel anlayış”, "yönetsel uygulama”, "insan kaynakları yönetimi uygulaması” ve "farklılıkların yönetimi” gibi yeni yaklaşımlar benimsenmiştir (Sürgevil, 2008, s. 112).

Bir toplumda sosyal huzurun sağlanması için ötekinin düşman olarak ilan edilmesi yerine, öteki olarak ifade edilen unsurun farklılı̆̆ını sosyal bir değere çevirmek gerekmektedir. Aksi takdirde sosyal huzurdan bahsetmek imkânsız bir hale gelebilecektir. Bu açıdan değerlendirildiği takdirde farklılıkların birer çatışma unsuru olarak görülmesi yerine, zenginlik kaynağı ve bir araya gelebilme aracı şeklinde değerlendirilmesi gerekmektedir. Dolayısıyla farklılaşma kavramının yalnızca doğuştan gelen özellikler ve kişisel yeterlilikler kapsamında değerlendirilmesi ve bunun bir zenginlik kaynağı olarak algılanması toplumsal düzeyde bir çatışma ortamının ortaya çıkmasına engel olabilecektir (Karaca, 2012, s. 227-228). 
$\mathrm{Bu}$ temel hedeften ve anlayıştan hareketle çalışmada farklılıkların gerçekte bir çatışma unsuru olmadıklarının ve bilinçli biçimde yönetilebildikleri takdirde toplumun zenginliğini oluşturduklarının vurgusu yapılmaya çalışılacaktır. Bununla birlikte, çalışmanın ruhunu oluşturan unsur farklılıkların başarılı biçimde yönetilmesi sonucunda "farklılıklar değerimizdir" vurgusunun yapılmasıdır. Bu kapsamda çalışmada ilk önce farklılık ve farklılıkların yönetilmesi kavramlarına değinilecek, toplumsal farklılıkların sebepleri, sonuçları ve unsurları konu edilecek, farklılıkların bir diğer çıkış noktası olan çokkültürlülük olgusu kavramsal boyutta değerlendirilecek ve nihai aşamada farklılıkların yönetilmesi konusu sivil toplum kuruluşları üzerinden kurgulanarak tamamlanmaya çalışılacaktır.

\section{Toplumsal Huzurun Sağlanmasındaki Temel Özne: Farklılık}

Rawls'a (2005, s. 126) göre toplum, karşılıklı bir biçimde yarar sağlayabilmek için işbirliği içerisine giren insanların oluşturmuş olduğu bir birlikteliktir. Bu birliktelik bireysel çıkar çatışması ile ortak faydaların buluştuğu bir noktayı tasvir etmektedir. İşte bu sebepten dolayı 'farklılık' kavramı iki uç nokta arasında gidip gelen hem uzlaştırmacı hem de ayrıştırmacı bir niteliğe sahiptir. Farklılık kavramının uzlaştırmacı veya ayrıştırmacı kimliği (Rawls, 2005, s. 126) açısından hangi yönde kullanılacağını belirleyebilmek için de "farklılıkların yönetimi” konusuna yer vermek gerekmektedir.

Üzerinde derin anlamlar taşıyan "farklılık" kavramının en yalın hali Türk Dil Kurumu Büyük Türkçe Sözlüğü’nde şu şekilde tanımlanmaktadır: "Farklı olma durumu, ayrımlılık, başkalık:...; Doğal, toplumsal ve bilince dayanan her olay ve olguyu bütün ötekilerden ayıran özellik." (Türk Dil Kurumu Büyük Türkçe Sözlük, Farklılık, Erişim Tarihi: 01.07.2018). Ancak özellikle Amerika Birleşik Devletleri (ABD) gibi çok kültürlü bir ulusa sahip bir ülkede farklılık kavramının kişiden kişiye, kurumdan kuruma ve yazardan yazara göre değişiklik göstermesinden dolayı, ilgili kavram hakkında kesin bir tanımlama yapmak oldukça zordur. Bazı kurum veya örgütler için farklılık kavramının temel hedefinde ırk, cinsiyet, din ve engellilik durumu yer alırken, diğerlerinin hedefinde ise cinsel eğilim, beden imgesi ve sosyo-ekonomik durum yer almaktadır (Washington, 2008, s. 3).

Farklılık kişisel bakış açısı ile ilgili bir kavramdır. Farklılık belirli bir grubun diğer gruplardan kendilerini ayırmak için kullandıkları bir sürecin kavramsal tanımlaması şeklinde ortaya çıkmaktadır. Farklılık kavramı, yukarıda da bahsedildiği üzere, bir gruptan diğer gruba göre değişiklik gösteren birincil ve ikincil boyutlara sahip bir yaklaşım tarzıdır. Birincil boyut kapsamında sıralanan cinsiyet, etnik köken, ırk, cinsel eğilim, yaş ve akıl ve bedensel engeller gibi unsurlar genel olarak bireylerin kimliklerini doğrudan açığa çıkaran özelliklere sahiptirler. Diğer bir yaklaşım tarzı ile birincil boyuta sahip olan unsurlar bireylerin öz benliklerini ve dünya görüşlerini ortaya çlkaran niteliklere sahiptirler. Bununla birlikte, bu unsurlar bireylerin iş ve sosyal yaşantısında etkileyici bir öneme de sahiptirler. İkincil boyuta sahip olan unsurlar ise toplumsal ilişkiler açısından daha az görünürlüğe sahip, ancak birey üzerindeki etkileri daha fazla olan etkenlerden meydana gelmektedirler. Bu etkenler farklılı̆̆ın birinci boyutunu tamamlayan, bireysel açıdan hemen göze çarpmayan ve kolay bir biçimde dikkat çekmeyen niteliktedirler. $\mathrm{Bu}$ 
nitelikler eğitim geçmişi, yaşanılan yer (mahalle, şehir, ülke vs.), din, anadil, ailenin maddi durumu, bireyin işi, çalışma şekli ve iş tecrübesi, gelir düzeyi ve iletişim becerileridir (Mazur, 2010, s. 5-6; Loden ve Rosener, 1991'den aktaran Mazur, 2010, s. 6).

Söz konusu yapılan beceriler, kendi alanı dışında yaşanan başka bir alanın içişleyiş düzenini algılayarak olası bir gerilimin ortaya çıkmaması için “empati” yeteneğinin varlığını zorunlu kılmaktadır. Bu noktadaki anahtar kavram “ötekini anlamak”tır. Böylece ötekinin deneyiminin veya varlığında barındırdığı değiştirilemez gerçeklerin anlamlandırılmasının dayanak noktası yaratılmış olmaktadır (Kaya, 2014, s. 16).

Bu birbirlerinden farklı gibi gözüken unsurların karşılıklı ilişkileri veya benzerlikleri buzdağı örneğini akıllara getirmektedir. Irk, cinsiyet, etnik köken, yaş ve engellilik durumu gibi ayrımcılık karşıtlığına konu olan bireysel farklılıklar buzdağının görünen yüzünü oluştururken, buzdağının görünmeyen kısmını oluşturan din, kültürel ve siyasi eğilimler daha az görünür nitelikte oldukları ve zaman içerisinde ortaya çıktıkları için ikincil boyutta yer aldıkları kabul edilmektedir. Bu görünen ve görünmeyen unsurlar karşılıklı iletişimin sağlanması ve toplumsal düzenin devam ettirilmesi için önem taşımaktadır (Mazur, 2010, s. 6). Bu noktada Friedrich A. von Hayek'in çözümsel yaklaşımına atıf yapılması önem taşımaktadır.

Friedrich A. von Hayek'e göre (2014, s. 311) ötekini anlamanın yolu bireysel erdemlerin sosyalleştirilmesinden geçmektedir. Bu ifade daha dayanaklı bir noktaya getirilmek istenirse, her şeyden önce, "bireyci erdemlerin" mutlak bir biçimde "sosyal erdemler" olarak anlaşılması gerektiği üzerinde yoğunlaşılmalıdır. Örneğin, "nezâket”, "espri duygusu”, "kişisel tevazu”, "komşusunun özel hayatına saygı" ve "iyi niyetine güven” gibi bireyci erdemler sosyal ilişkilerin olumlu yönde olmak üzere belirli bir düzende sürdürülmesi ve farklılıklardan kaynaklanan olumsuzlukların en aza indirilmesi için gerekli olan konu başlıklarını oluşturmaktadırlar (Hayek, 2014, s. 311).

\section{Farklılıkların Yönetimi: Kavramsal Çerçeve}

Farklılık kavramının odak noktasına yerleşen insan farklılıkları yaşamın tüm alanlarında üzerinde önemle durulması ve yönetilmesi gereken bir olgudur. Bu olgu özel veya kamusal alan ayrımı yapılmaksızın üzerinde çalışılması gereken bir durumu ortaya çıkartmaktadır. Çünkü belirli bir sayıda ve belirli bir amacı gerçekleştirmek için bir araya gelmiş insan topluluğunun sahip olması gereken uyum ve çalışma birlikteliği örgütlerin başarısı ve hedeflerine sorunsuz bir biçimde ulaşması için önem taşımaktadır. Önceden belirlenen hedefleri gerçekleştirmek için bir araya gelmiş olan insanlar örgüt hedefleri ve bireysel özgürlükler arasında sıkışmış durumdadırlar. Bu noktada insan, örgütün hedeflerine ulaşması için diğer insanlarla herhangi bir soruna sebep vermeyecek bir biçimde uyum içerisinde çalışma zorunluluğu içerisine girerken, diğer yandan da cinsiyet, yaş, engellilik vb. gibi farklılıklarından da taviz vermek istememektedir. İnsanların bu amaçlar arasında yaşamış oldukları ikilem "farklılıkların yönetimi” kavramını ortaya çıkartmaktadır (Sosyal ve Yalçın, 2013, s. 28). 
Toplumun yönetilmesi alanında en önemli görevi üstlenen unsur devlettir. Çünkü devlet, bireylerin ve toplulukların kendi aralarındaki dayanışma duygusunun geliştirilmesi ve sürdürülmesi aşamasında önemli görevler üstlenmektedir. Bu bağlamda değerlendirildiği takdirde devlet, çözümsel anlamda, bireyler ve topluluklar için "merkezi” bir noktada konumlanmaktadır. Devlet kanun yapma ve uygulama gücü sayesinde toplumsal “dayanışmanın” sağlayıcılığı görevini üstlenmektedir. Gianfranco'nun (2012, s. 157) ifadesi ile “... devlet, tümü ya da bir bölümü adına, toplumu yönetmek için oluşturulmuştur.” (Gianfranco, 2012, s. 157).

R. Roosevelt Thomas Jr., 1983 yllında Amerikan Farklılıkların Yönetimi Enstitüsünü (American Institute for Management Diversity) kurmuştur (Fettahlığlu ve İnce, 2013, s. 78). Bu sebepten dolayı farklılıkların yönetimi kavramının ortaya çıktığı yerin ABD olduğu kabul edilmektedir. Farklılıkların yönetimi kavramının hedefinde kültür, yaşam tarzı, eğitim düzeyi, fiziksel görünüm, iş tecrübesi, etnik köken, yaş, cinsiyet, cinsel eğilim, siyasi görüş ve hayata bakış açısı gibi birbirlerinden farklılık gösteren unsurların bireyler arasında herhangi bir ayrımcılığa sebebiyet vermemesini öngören bir yönetim modelinin kurgulanması düşüncesi yer almaktadır. Farklılıkların yönetilmesi düşüncesi altında örgüt içerisinde yer alan bireylerin farklılıklarını kullanarak örgütün verimliliğini arttırmak hedefi yer almaktadır (Sosyal ve Yalçın, 2013, s. 28). Bu hedef kapsamında farklılıkların yönetimi yaklaşımının, odaklanılan amacın gerçekleştirilmesi için yöntem olarak belirlenecek yol haritasının ve başlatılan süreçte uygulanacak stratejilerin, kurumsal bir maliyet getireceği inancı yerine, kazanımlı bir sonucun ortaya çıkacağı düşüncesi kapsamında yorumlanması ve anlamlandırılması gerekmektedir (Sürgevil, 2008, s. 113).

Diğer bir yaklaşım ile "Farklılıkların yönetimi bireylerin örgütün stratejik hedef ve amaçlarına en yüksek düzeyde katkı sağlayabilmeleri ve kendi potansiyellerine ulaşabilmeleri için bireysel benzerliklere ve farklılıklara değer verilen bir iş çevresi yaratmak ve bunu devam ettirmek amacıyla oluşturulmuş bir süreçtir.” (United States Government Accountability Office, 2005, s. $1)$.

Özel veya kamu kurumlarındaki yöneticilerin farklılıkları ortadan kaldırmak yerine, bu farklılıkları kurum adına en etkili biçimde kullanabilmeleri için farklılıkları yönetebilme yeteneğini kazanmaları gerekmektedir (Sürgevil, 2008, s. 113). Çünkü bir yöneticinin en önemli görevlerinden birisi sorumluluğu altında bulunan bireylerin nasıl yönetileceğini ve onlara iş yaptırırken hangi yöntemleri kullanarak sonuca ulaşacağını bilmektir (Simon vd., 1985, s. 19).

Farklılıkların yorumlanamadığı, kabul edil(e)mediği ve iyi yönetil(e)mediği durumlarda bireysel farklılıklar toplumsal düzeyde sorunlara sebebiyet verebilmektedir. Farklılıklar toplumsal çeşitlilikten kaynaklanmaktadır. Bu çeşitliliğe karşı önyargılı bir tavır ile yaklaşmak ve olumsuz davranışlar sergilemek farklılıkların faydalı birer unsur olabilmelerinin önüne geçebilmektedir. Dolayısıyla farklılıkları olumsuzluk olarak değerlendirmek yerine bir fırsat olarak algılamak toplumsal bütünlüğün sağlanabilmesi adına gerekli bir yaklaşım tarzını meydana getirmektedir. Bu hedefe ulaşabilmek için de "farklılıkların yönetimi" anlayışına önem vermek gerekmektedir (Güleş, 2012, s. 617). Örneğin, bir işletmede çalışan çok sayıda kişinin birbirlerinden farklılık 
gösteren özelliklerinin bir ayrışma unsuru olarak değil, işletmenin daha üretken ve verimli biçimde çalışabilmesi için bir fırsat olarak değerlendirilmesi gerekmektedir (Fettahlıoğlu ve İnce, 2013, s. 78).

Bu noktaya kadar anlatılanlardan farklılıkların yönetimi kavramının özel ve kamu sektörünün iş hayatı için kurgulanmış olduğu gerçeğine ulaşılması güç değildir. Ancak farklılıkların yönetimi kavramının toplumsal düzeyde genişletilerek bir toplumun parçalarını oluşturan bireylerin farklılıklarından dolayı herhangi bir olumsuzluğa veya dışlama hareketine yer vermeden olduğu gibi kabul edilmesi ve bu farklılıklardan faydalanılması şeklinde anlamlandırılması ve bu değerden faydalanılabilmesi için gerekli olan eylem planlarının hazırlanması gerekmektedir. Çünkü toplumu "tek tipleştirmek" toplumun güzelliklerini oluşturan değerlerin görülmemesine sebep olmaktadır (Demir, 2018, s. 249-262).

\section{Toplumsal Farklılıkların Etkileri}

Toplumsal farklılık bir başlangıç noktası değildir. Toplumsal farklılığın bir başlangıç noktası olarak anlamlandırılamamasının sebebi açıklanabilir bir sürecin tamamını oluşturmasından kaynaklanmaktadır. Daha kısa bir açıklama ile toplumsal farklılık bir sonuç değil, bir süreçtir. Bu sürecin sonucu ise "sosyal farklar"dır. Sosyal farklar, toplumsal ayrımlaşmanın ürettiği bir sonuçtur. Toplumsal alanda yaşanan farklılıklar sosyal sınırlar ile örgülenmiş bir dünyanın olası sonuçlarını oluşturmaktadır. Bu sınırlar yapısal varoluşun, yaşam biçiminin veya yapısal uyarıcılığın sürekli tekrarlanan sosyal ilişkiler ve hayat tecrübeleri ile doğrulanması sonucunda oluşmaktadır (Juteau, 2003, s. 10).

Toplumsal farklılaşma ve bu farklılaşmadan kaynaklanan katmanlaşma hemen her toplumda görülebilecek bir sonuçtur. Gerçekte bir toplum jeolojik katmanlar gibi birbirlerine bağlı unsurlardan meydana gelmektedir. Bu unsurların birbirlerinden farklı özellikler göstermesi toplumsal farklılaşmayı meydana getirmektedir. Bu açıdan değerlendirildiği takdirde bir toplum kendi içerisinde gelir (maddi kazanç), sağlık, meslek, eğitim ve güç gibi unsurlar bağlamında farklılaşabilmektedir. Bir toplum içerisinde söz konusu yapılan bu farklılık unsurlarının eşit biçimde toplumun geneline dağıtıldığını ifade etmek kolay bir uğraş değildir (Beeghley, 2016, s. $1)$.

Toplumsal farklılık, bir noktada, toplumsal kaynakların bireyler ve topluluklar arasında eşitsiz biçimde dağılması sorununu meydana getirmektedir. Bu sorun (Guo, 2016, s. 1) toplumsal ilişkilerin hiyerarşik bir düzen içerisinde sürdürülmesinden kaynaklanan sebeplerden dolayı tüm yönleri ile birlikte analiz yapmayı gerektirmektedir. Bu sebepten dolayı sosyal, ekonomik ve kültürel alanlarda meydana gelen toplumsal eşitsizlik unsurlarının, toplumsal farklılaşma konusu içerisinde incelenmesi gerekmektedir (Bottero, 2005, s. 11).

Farklılıklar çoğu zaman ortaya çıkan olumsuzluklar olarak değerlendirilmektedir. Bu sebepten dolayı farklılıklara mesafeli yaklaşılması gerektiği şeklinde bir önyargı ortaya çıabilmektedir. Gerçekte farklılıklar, bireylerin özel yeteneklerinin ortaya çıkması ve insan ilişkilerinde karşılıklı iletişimin sağlıklı temellere oturtulabilmesi için bir firsat olarak değerlendirilmesi gereken değerler bütünüdür (Sürgevil, 2008, s. 113). 
Farklılıklar değişik arka plana ve önemli niteliklere sahip çok sayıda bireyi bir araya getiren bir değere sahiptir. Farklılıkların faydaları özellikle özel sektörde daha fazla görülmektedir. Bireyler farklılıkların yoğun olduğu bir çevrede daha fazla fikir alışverişinde bulunabilmekte ve karşılıklı olarak etkileşime girebilmektedirler (Washington, 2008, s. 4).

Farklılıkların etkili biçimde yönetilebildiği toplumlarda farklılıklardan kaynaklanabilecek olumsuzlukların en aza indirilebilmesi için gerekli olan zemin yaratılmış olmaktadır. Örnek vermek gerekirse, ABD toplumunun \%28'i rrksal ve etnik azınlıklardan oluşmaktadır. ABD’nin her geçen yıl çeşitlenen toplumsal yapısından dolayı bu oranın 2030 yılında \%30'a yükseleceği tahmin edilmektedir. Bu oran ABD nüfusunun üçte birini oluşturmaktadır. Bu gibi bir yüksek oranda toplumsal farklılığa sahip bir devletin değerlerini oluşturan farklılıkların yok sayılması, görmezden gelinmesi veya üzerine önemle eğilinmemesi durumunda toplumsal huzurun sağlanmasını beklemek gerçekçi bir tablonun ortaya çıkmasına engel olabilecektir. Bu sebepten dolayı bir devletin sahip olduğu farklılıklara önem vermesi ve toplumun genel kazanımları için bu farklılıkları etkili biçimde yönetmesi toplumsal huzurun sağlanabilmesi adına önem taşımaktadır. Çünkü farklı gruplar arasındaki iletişim ve işbirliği geliştirilebildiği takdirde kültürler arasındaki anlayışın, birlik ve beraberliğin geliştirilmesi mümkün olmaktadır. $\mathrm{Bu}$ sayede farklı kültürlere ve niteliklere sahip grupların hoşgörü içerisinde sorunsuzca bir arada yaşamaları sağlanmış olacaktır (Fettahlıoğlu ve İnce, 2013, s. 79-81). Çünkü toplumsal farklılık bir toplum içerisinde kültürel farklılıktan dolayı ortaya çıkan bir sonuçtur. Diğer bir ifadeyle, toplumsal farklılık aynı toplum içerisinde yaşayan ve farklı karakteristik özellikler taşıyan çeşitli kimliklere sahip insanların bir arada yaşamasından kaynaklanan bir sonucu ifade etmektedir. Bu farklı unsurlar bir toplum içerisinde azınlık veya çoğunluk konumunda bulunabilmektedirler. Özellikle azınlık grupların çoğunluğa karışması, geçmişten getirmiş oldukları kültürel zenginlik sayesinde, toplumu canlandırmaktadır. Böylece bu azınlık grupları daha üstün veya kazanımlı bir konuma gelmektedirler. Bu farklılıkların yönetilmesi ise bireylerin kendi potansiyellerini topluma yansıtmaları açısından bir firsat olarak değerlendirilmektedir (Helvacıoğlu ve Özutku, 2010, s. 198).

\section{Toplumsal Farklılığa Sebep Olan Unsurlar}

Toplumsal farklılıkların ve bu farklılıklardan kaynaklanan uzlaşmazlıkların temelinde bireyler arasında var olan farklılıklar yer almaktadır. Gerçek anlamda bir birlikteliğin tek tipleşmenin yoğun olduğu veya tek tip özellik gösteren benzer türler arasında değil, birbirlerinden özleri itibarıyla farklılık gösteren çok tipli ve birbirlerine benzemeyenler arasında yaşanabileceği görüşü kabul görmektedir (Karaca, 2012, s. 227-228). Oysaki ilk zamanlarda toplumsal farklılıkların ortaya çıkması bireysel farklılıkların varlığı bağlamında açıklanmamaktaydı. Düzeltilmiş bir ifade ile bireysel farklılıklar toplumsal farklılıkların oluşumu için öncü bir sebep olarak kabul edilmemekteydi (Mark, 1998, s. 310).

Ancak kabul etmek gerekir ki tüm insanlık tarihi kısa bir biçimde gözden geçirildiği takdirde insanların doğuştan getirdiği cinsiyet, ırk, dil, din, ten rengi, zekâ düzeyi vb. gibi özelliklerinin yanı sıra sonradan kazanılan boy, kilo, servet, eğitim, itibar vb. gibi özelliklerinde de tek tip bir uygulamaya rastlamak olanaksız gibi görünmektedir. Dolayısıyla insanlar arasında fiziksel 
özelliklerinden sosyal niteliklerine kadar geniş bir çerçevede farklılaşma her zaman var olmuş ve olmaya da devam etmektedir (Karaca, 2012, s. 228). Bu farklılaşma, genel anlamda, "dil”, "din” ve "ahlak" gibi insan hayatında kalıplaşmış ve evrimsel nitelik taşıyacak biçimde varlığını sürdüren değerler üzerinden gerçekleşmektedir. Örneğin, dil, bireylerin sonradan düşünüp kurguladığı bir yetenek biçimi değil, insanın doğası içerisinde yer alan ve evrimsel süreç içerisinde ortaya çıkan bir değerdir (Yayla, 2000, s. 129).

Söz konusu edilen değerlerin ışığında konuya devam etmek gerekirse sosyal niteliğe vurgu yapmak önem taşımaktadır. Sosyal açıdan yapılacak bir değerlendirme bağlamında farklılık veya farklılaşma, akraba saygınlığına göre mesleklerin derecelendirmesi ve ailelerin ve tek tek bireylerin başarıları ile kişisel yetenekleri dikkate alındığı durumda, eşitlikçi ideolojiye ve bireysel farklıkları deneyleyebilecek birçok yönteme rağmen, açık bir biçimde fark edilebilmektedir (Garbier, 1952, s. 340).

\section{Etnik Çeşitlilik}

Etnik terimi 14. Yüzyıl'ın ortalarından 19. Yüzyıl'ın sonlarına kadar Hristiyan olmayan ve kâfir olarak adlandırılan kişiler, paganlar ve batıl inançlara sahip olan insanlar için olumsuz anlamda kullanılmış olmakla birlikte, zaman içerisinde kullanım yeri ve anlamı bağlamında değişimler yaşanmıştır. Bu dönüşümün ruhunda ırk kökeninin farklı olmasından dolayı azınlıkta kalmak istemeyen grupların özgürlük ideali çağrısı yer almaktadır. Bununla birlikte, bir bütün halinde düşünülen bir toplumun gerçekte farklı ve güçleri eşit olmayan ırklara bölünmüş olduğu fikri bu çağrının öneminin artmasına vesile olmuştur (Nişancı ve Işık, 2012, s. 110).

Etnik kavramı antropolojik bir yaklaşım ile değerlendirildiği takdirde (çoğu zaman bu anlamı ile algılanmaktadır) ömür boyu devam eden biyolojik bir miras şeklinde anlamlandırılmaktadır. Bu miras temel kültürel değerlerin açık bir biçimde kültürel kalıplara sıkıştırılması ile yoğrulmuş bir eksen etrafında biçimlenmektedir. Böylece alansal açıdan dar, ancak birincil seviyede iletişim ve etkileşim ortamı yaratılmış olmaktadır. Bireylerin kendilerini tanımlayabileceği ve diğerlerinin de bireyleri aynı anlam doğrultusunda niteleyebileceği bir kalıp ortaya çıkmaktadır (Barth, 1998, s. 10-11).

Anthony D. Smith'e göre ise etnik ortak bir atadan gelmiş, kültürel bağlar üzerinden birbirleri ile ilişkilendirilmiş, ortak değerler bağlamında hareket eden insan topluluğuna atıf yapmak için kullanılan bir kelimedir. Bu anlam çerçevesinde açıllamalara devam edilmesi gerekirse etnik kelimesinin vatan ve millet özelinde bir “dayanışma ölçüsü” olarak da kullanılması mümkündür (Smith, 1993, s. 28-29).

Etnik kökene dayanan farklılaştırma bireylerin ırksal konumuna atıf yapmaktadır. Irksal farklılıklardan kaynaklanan eşitsiz ve ayrıştırmacı yaklaşımlar, bireyler üzerinde "üstünlük (superiority) algısı" yaratmaktadır. Bir diğer anlamlandırma ile bir ırkın diğer bir ırk üzerinde üstün konumda bulunduğu önkabulü ırksal farklılaşmayı hiyerarşik bir anlayış çerçevesinde yeniden yorumlamaktadır. Bu yorumlayış biçimi ise etnik kökene dayanan farklılaşmayı eşitsiz bir ortam özelinde yeni anlamlara yönlendirmektedir (Odabaş, 2018, s. 177). 
Bir azınlığ 1 etnik bir grup olarak nitelendirebilmek için yalnızca farklı bir yerel dili konuşuyor olmaları araçsal açıdan yetmemektedir. Bunun için ilgili grubun "ana kültür kalıpları" olarak ifade edilebilecek dil, din, adet, gelenek ve kültür vb. unsurlarının yaşam tarzlarını doğrudan etkileyerek değiştirmesi gerekmektedir. Diğer bir anlatım ile ana kültür kalıplarının baskın toplum içerisinde farklılık göstermesi gerekmektedir. Böylece etnik grup baskın toplumdan ayrışarak kendi öz toplumsal kimliğini kazanmış olacaktır. Bu noktada baskın toplum olarak adlandırılan unsurun diğer etnik kökenler arasında en fazla güçlü olan grup olduğunu vurgulamak gerekmektedir. Etnik kimliğin veya kökenin ortaya çıkmasının temel koşulu da baskın gruptan sosyal ve kültürel anlamda tamamen ayrışabilme yeteneğinin gelişmesidir (Nişancı ve Işık, 2012, s. 110).

Etnik çeşitliliğin oldukça yüksek olduğu yoksul veya gelişmemiş ülkelerde gruplar arasında değer, yargı, kural ve tavırlar farklılık gösterebilmektedir. Bir diğer ifadeyle, farklılığı oluşturan unsurlar özelinde bir yükselme gözlemlenebilmektedir (Desmet vd., 2017, s. 1).

Will Kymlicka'nın (1995, s. 3) görüşüne göre etnik kimlik ve dini inanç bireyin kendi içerisinde yaşadığı ve devletin müdahale etmesi kabul görmeyen özerk alanlardır. Etnik kimlik konusu, özerk bir alan olmasından dolayı, devletin ilgi alanına girmemektedir. Bu aşamada devlet bireylerin etnik kimliği hakkında farklılaştırma çalışması içerisine giremediği gibi, birtakım söylemler ile destekleme faaliyetlerinde de bulunması kabul edilmemektedir (Kymlicka, 1995, s. $3)$.

Etnik anlaşmazlıklar siyaset, ekonomi, sosyal, kültürel ve bölgesel konular üzerinden en az iki veya daha fazla etnik topluluk arasında bir çatışmaya dönüşebilmektedir. Bazı etnik anlaşmazlıklar küçük çapta şiddet gösterilerine sahne olurken, sürecin işleyiş düzenine göre herhangi bir çatışma ortamı ortaya çıkmayabilmektedir (Brown, 1993, s. 5). Ancak kabul edilmesi gerekir ki etnik farklılıklar herhangi bir şiddet eylemine tek başına sebep ol(a)mamaktadır. Birçok etnik topluluk kendi farklılıklarını bir diğer topluluğa veya devlete şiddet eylemleri üzerinden değil, barış̧̧ıl ve siyasi yöntemleri kullanarak kabul ettirmeye çalışmaktadırlar (Lake ve Rothchild, 1998, s. 7).

\section{Kültürel Çeşitlilik}

Kültür zaman ve var olduğu ortam içerisinde değişime uğrayarak yaşadığı toplumun bireyleri üzerinde etkide bulunmaktadır. Bu etki bireylerin kimlikleri üzerinde olabildiği gibi yaşam biçimlerinde de gözlemlenebilmektedir. Doğal yaşamı zenginleştiren ve devamını sağlayan biyolojik çeşitlilikte gözlemlendiği gibi tek tipleşmeden uzak toplumsal ve kültürel çeşitlilik de insan ırkının değişim, yenilenme ve yaratıcılık kaynağı olarak kabul görmektedir (UNESCO Kültürel Çeşitlilik Evrensel Bildirgesi, Erişim Tarihi: 15.07.2018). Bu anlamda değerlendirildiği takdirde kültürün genetik bir miras olmadığı, sonradan çevresel etkilerle öğrenilebilecek bir unsur olduğu ifade edilebilmektedir (Spencer-Oatey, 2012, s. 6). 
Yaşanılan yüzyıl içerisinde kültürün çevresel etkilere açık bir konuma gelmesi bilinen her şeyin kültürleşmeye başlaması ile yakından ilişkilidir. Kültürleşme, herkesin kendi kültürü içinde kalarak kendi benimsediği değerleri bir "kültür dünyasına" dönüştürmesi şeklinde açıklanabilmektedir. (Sarıbay, 2014, s. 47). Bu açıklamanın karşıt durumunu ise kültürel çeşitlilik oluşturmaktadır. Bu noktada yapılacak kısa bir yoruma göre farklı kültürlerin öncelikle kendi iç dünyasında bütünlük kazanmadan, birleşme veya bütünleşme çabası içerisine girmesi, olmayan bir kültür bilincinin çeşitlilik içerisinde bütünleştirilmesi anlamına gelmektedir. Böyle bir durumda ise kültürel çeşitlilikten söz edilmesi oldukça zordur (Demir, 2018, s. 251-253; Yaylacı, 2017, s. 351-355, 361).

Gelinen noktada ise kültürel çeşitlilikten söz edilmesi ile ulaşılmak istenen hedef etnik ve ulusal farklılığa vurgu yapmaktır. Çünkü Kymlicka’a göre kültür “ulus” veya "millet” ile eş anlamlıdır. $\mathrm{Bu}$ bağlamda değerlendirildiği takdirde kuşaklararası toplumun kültürel devamlılı̆̆ını sağlayabilmek için belirgin bir ortak dil ve tarihe ihtiyaç duyulmaktadır (Kymlicka, 1995, s. 18).

\section{Dinsel Çeşitlilik}

Dini çeşitlilik, özellikle Batı'da son yıllarda tartışılan konuların ön sıralarında yer almaktadır. Dinler arasında var olan farklılıklar dinlerin çeşitliliğini ortaya çıkartmaktadır. Böylece dinler arasında belirli noktalarda uyuşmazlıkların meydana gelmesi de doğal bir süreci yansıtmaktadır. Çünkü dinlerin getirmiş olduğu öğretilerin genel anlamda "test edilmesi” oldukça güçtür. Dolayısıyla birbirleriyle çelişen din anlayışları dinlerin çokluğunu bir problem olarak gündeme taşımaktadır (Arıcan, 2011, s. 72).

Dinlerin ortaya çıkması aşamasında bilinen gerçek her dinin temel öğretisinin farklı sınırlar(a) veya değerlendirme konularına karşı yeni bir yaklaşım sergilemiş olmasıdır. Çerçevesi çizilmiş bu sınırlar ile meşgul olurken insan zihninin hedeflediği temel nokta, insanın bu sınırlar içerisinde nasıl yaşayacağı ve gerektiği durumda da bu sınırları nasıl aşacağıdır (Albanese, 2012, s. 3-5).

Hedeflenen bu noktaya ulaşma aşamasında dinlerin çeşitliliği vatandaşlık kimliğine yer bırakmamaktadır. Böyle bir durumun varlığında ise sağlıklı bir demokrasinin işletilmesi oldukça zor görülmektedir. Eleştirel bir yaklaşımın sergilenmesi gerekirse kimliksel bilincin bu şekilde parçalanması ve din çeşitliliğinin vatandaşlık kimliğini yıpratması, gerçekte, çokkültürlülüğün olumsuz sonuçlarından birisini oluşturmaktadır (Kymlicka ve Norman, 2003, s. 35).

\section{Dilsel Çeşitlilik}

Sözlü olarak kurulan iletişim ve bunun aracı olan dil (lisan) yeteneği insanoğlunu diğer canlı türlerinden ayıran en önemli niteliğidir. Dünya üzerinde konuşulan yaklaşık olarak 7000 dil insanlar arasında sözlü iletişimi sağlamaktadır. Dil, sembollerin sözlü hale getirilmesi olarak anlamlandırılmakla birlikte, uygarlıklar arasında kurulan iletişim kültürel alış verişi mümkün kılmaktadır (Ekici, 2012, s. 46-47). 
Dil çeşitliliğinin en açık bir biçimde görülebileceği Avrupa Birliği çoklu millet yapısı ile bünyesinde çok fazla dilin konuşulduğu bir yapılanmayı meydana getirmektedir. Bu sebepten dolayı Avrupa Birliği çok dilliliğe ve dillerin çeşitliliğine ayrı bir önem vermekte ve Birlik içerisinde dillerin çeşitliliğinin "siyasi gerekliliği” kabul görmektedir (Gündüz, 2006, s. 200).

\section{Eğitim Çeşitliliği}

Eğitim, bir toplumun kendi geleceğini inşa edebilmesi ve etnik, kültürel, dinsel ve dilsel çeşitliliğini devam ettirebilmesi için önemli bir araç niteliğindedir. Diğer bir anlatım şekli ile eğitim toplumsal değerlerin bir sonraki kuşağa aktarılmasını sağlamaktadır. Dolayısıyla eğitimin kurumsallaşması toplumsal çeşitliliğin devam ettirilebilmesi adına önem taşımaktadır (Canatan, 2009, s. 91). Bununla birlikte, vatandaşların ihtiyaç duyduğu etkili siyasi yeterliliğe kavuşabilmeleri için gerekli olan alt yapı da eğitim sayesinde oluşturulmaktadır (Saha, 2007, s. 13). Çünkü eğitimin temel amaçlarından birisi nesiller arasında, kültür başta olmak üzere, toplumsal değerlerin aktarımını sağlamaktır (Dhawan, 2005, s. 22).

\section{Toplumsal Bir Değer: Çokkültürlülük}

Günümüzde yaşayan yüzlerce dil, etnik köken ve farklı kültürlerin varlığı ve modern devletlerin neredeyse tamamının heterojen bir yapıya sahip olmaları azınlıkların kendi farklılıklarını yaşama ve kendi kültürel değerlerine saygı gösterilmesi talepleri ile sonuçlanmaktadır. Her birey kendi öz varlığı ile bir değer taşımakta ve böylece farklı dil, din, etnik köken, renk, cinsiyet ve kültür unsurlarının da devamlılığını sağlamaktadır (Erincik, 2011, s. 226).

Çokkültürlü bir toplum düzeni içerisinde kimliklerin "farklılıklar üzerinden inşa” edilmesinden dolayı (Düzgit, 2014, s. 87) toplumsal bütünlüğün sağlanabilmesi için farklılıkların yönetilmesine ihtiyaç duyulmaktadır (Demir, 2018, s. 249).

Çokkültürlülük en genel anlamı ile bir toplum içerisinde iki veya daha fazla sayıda kültürel çeşitliliğin ve azınlıkların bulunduğu topluma vurgu yapmaktadır. Küreselleşme ile birlikte dünyanın neredeyse hiçbir yerinde kendi kalıpları içerisine sıkışmış ve homojen bir biçimde yaşayan bir toplum görülmediği düşünülmektedir. Dolayısıyla her toplumun heterojen yapısı ile çokkültürlü bir toplum olarak değerlendirilmesi yanlış olmayacaktır (Erincik, 2011, s. 226).

Avrupa özelinde çokkültürlülük kavramı tartışmalarının kökenine ulus devletlerin kurulma sürecinde rastlanabilmektedir. Ulus devlet anlayışı ilk olarak Avrupa'da farklı dil, din ve kültürlerin ortak bir noktada buluşturularak farklılıklarından kaynaklanan olumsuzlukların giderilmesi amacıyla ortaya çıkmıştır. Bu farklılıkları aynı potada eriterek ortak bir tarih, dil ve kültür yaratmak amacı çokkültürlülük kavramını da sorgulamaya açmıştır. Çokkültürlülük kavramı bir toplum içerisinde tektipleşmeyi, kalıpsal birliği ve sorgusuz ortaklığı bozan “çeşitlilik" kavramı ile doğrudan ilişkilidir (Canatan, 2009, s. 80).

Çokkültürlülük bir inanç sistemi ve davranış kalıbı olarak farklı kaynaklardan beslenen semantik bir yapıya sahiptir. Bu yapı içerisinde toplumun her unsuru kendi öz benliği ile var olmakta, tanınmakta ve saygı duyulmaktadır. İlgili unsurların sosyo-kültürel değerleri bağlamında topluma yapmış oldukları katkı(lar) toplumu bir bütün olarak daha güçlü bir konuma 
getirmektedir. Çokkültürlülügün varlığı farklılıkları meydana getiren sinırları dışlayarak farklılıklardan bütün oluşturan yetenek ile doğrudan ilişkilidir. Bir diğer bakış açısına göre ise çokkültürlülük farklılıklardan bütünlük yaratma yeteneğini kendi özünde taşıyan bir kurguya sahiptir. Bu kurgu farklılıkları yönetme sanatı olarak da yorumlanabilecek sonuçları ortaya çıkartmaktadır. Bir diğer anlatıma göre ise çokkültürlülük farklılıkların yönetimi sanatıdır. Bu sanat içerisinde toplumun hiçbir unsuru toplum halkası dışına itilmemektedir. Bu durum, aynı zamanda, etnosentrizm uygulamalarına karşı bir güvenlik önlemi olarak da algılanabilmektedir (Budrina, 2019, s. 12-13).

Çokkültürlülük bir devletin siyasi politikalarını ve uluslararası ilişkilerini etkileyen bir niteliğe de sahiptir. Ulusların var olma çabası bağlamında bir strateji geliştirebilme yeteneği çokkültürlü ortamda kendisini gösterebilmektedir. Örneğin, Avrupa Birliği gibi farklı ulusları aynı zeminde ortak hareket etmeye zorlayan bir yapılanma için çokkültürlülük üzerinde durulması gereken önemli bir konu başlığını oluşturmaktadır. Bu yaklaşım çerçevesinde farklılıkların sosyal sorunlara sebebiyet vermeden yönetilebilmesi ve çoğulcu bir zihniyetin çözüme katk1 sağlayabilmesi için ulusların ve uluslararası yapılanmaların çokkültürlülük unsurunu çözüm aracı olarak kullanması önem taşımaktadır (Horsti, 2011, s. 157).

Çokkültürlülük konusunda yapılan tartışmalar analiz edildiğinde ilgili kavramın gerçekte derin bir arka planı olduğu gerçeğine ulaşılabilmektedir. Bu analizler kısaca şu şekilde siralanabilmektedirler (Canatan, 2009, s. 83):

- Çokkültürlü yapıya sahip bir toplumda farklı etnik gruplar arasında kültürel farklılıklardan kaynaklanan çatışmalar yaşanabilmektedir. Bu çatışma beklentisinin temelinde farklı kültürlerin ve diğer farklılıkların uygulamada birbirleri ile uyuşamayacağı görüşü veya öngörüsü yer almaktadır.

- Etnik grupların toplumun tamamı ile uyum içerisinde yaşayamamalarının ve topluma dâhil olamamalarının sebebinin kültürel farklılıkların dışlayıcı niteliğinden kaynaklandığı yönünde görüşler bulunmaktadır.

- Batı kültürünün diğer kültürlere göre daha üst sırada yer aldığı önyargısından hareketle diğer kültürlerin dışlanması mümkün (veya söz konusu) olabilmektedir.

Çokkültürlülük kavramsal olarak tektipleşme yerine farklılaşmayı öngörmektedir. Farklılaşma olgusu bir ülkenin yönetim politikalarına da yansıyabilmektedir. Farklılaşma ile doğrudan bağlantılı kullanılan çokkültürlülük kültür, dil, etnik köken, yaşam biçimi ve din alanlarında tektip bir model yerine her bireyin veya topluluğun farklılığına saygı gösterecek toplumsal bir yapının oluşturulmasını öngörmektedir (Vatandaş, 2001, s. 102).

Toplumsal yapının saygı ve hoşgörü üzerine kurulması, kabul edilmesinin zor olduğu veya kabul etmek konusunda kararsızlığa düşüldügü farklılıkların benimsenmesi noktasında ortaya çıkan katlanma maliyetini en aza indirmektedir (Kaya, 2014, s. 30).

Çokkültürlülük toplumsal bir model olarak azınlıkları yok sayan ve tektipleşme ile mücadele eden, farklılıkları toplumun değeri olarak görerek koruma altına alan bir yapıya sahiptir. $\mathrm{Bu}$ 
toplumsal modelde çok fazla sayıda farklılık bulunmakla birlikte, hiçbir aşamada bu farklılıkların eritilmesi düşüncesi içerisine girilmemekte, aksine her farklılığın kendi özü itibarıyla yaşatılması hedeflenmektedir. Farklılıklar özünü kaybetmeden birbirleri ile karıştırıldığı durumda "yeni bir aroma” ortaya çıkmaktadır (Vatandaş, 2001, s. 104).

\section{Toplumsal Farklılığı Yönetmek}

Avrupa'da toplumsal farklılıkların en yoğun biçimde yaşandığı ülkelerden biri ve hatta en önemlisi İsviçre'dir. İsviçre genel olarak heterojen bir yapılanmaya sahiptir. Bu gerçeğe, sınırları diğer Avrupa ülkeleri ile karşılaştırıldığında oldukça dar olan bir ülkede çok sayıda konuşulan dilden ulaşılabilmektedir. İsviçre'de Almanca, Fransızca, İtalyanca ve Romansça resmi dil olarak konuşulmaktadır. Diğer bir ifadeyle, İsviçre'nin tek bir resmi dili bulunmamaktadır. İsviçre'de bu gerçek kültürel zenginlik olarak değerlendirilmektedir. İsviçre’nin kültürel zenginliği yalnızca konuşulan farklı diller ile sınırlı değildir. Söz konusu çeşitlilik inanılan din açısından da devam etmektedir. İsviçre'de Katolik, Protestan, Müslüman, Ortodoks ve hiçbir dine inanmayan insanlardan oluşan bir toplum yapısı bulunmaktadır (Ergil, 1995, s. 162).

ABD, Kanada ve Yeni Zelanda örneklerinde görüldügü gibi İsviçre göçmen nüfusun çok fazla olduğu bir yapıya İkinci Dünya Savaşı’ndan sonra ulaşmıştır. Göçmenlerin kendileri ile birlikte getirdikleri yaşam kültürleri coğrafyaya kültürel zenginlik aşılamıştır. Benzer biçimde, İkinci Dünya Savaşı sonrasında Almanya, Fransa, İngiltere, Hollanda ve Belçika göçmen nüfusun yoğunlaştığı ülkeler konumuna yükselmiş ve Avrupa'nın önemli bir bölümünde, savaş gibi büyük bir felaketin ardından kültürel zenginlik veya çokkültürlülük yaşanmaya başlamıştır (Kaya, 2014, s. 25).

Ergil (1995, s. 162) yüzölçümü açısından bu kadar küçük bir ülkenin farklılıklardan rahatsız olmadan nasıl huzurlu bir biçimde varlığını devam ettirebildiğini sorgulamak amacıyla; "İsviçre, nüfusu küçük ve homojen oldugu için mi istikrar ve huzur bulmuştur?” (Ergil, 1995, s. 162) sorusunu yöneltmektedir. Bu soru Ergil (1995, s. 162) atıf gösterilerek şu şekilde de sorulabilmektedir: 'İsviçreliler bu kadar karışık bir kültür tablosu içerisinde yaşarken birbirleri ile uyumlu olmayı nasıl başarmışlardır?’

Ergil (1995, s. 163-164) bu soruyu İsviçrelilerin artık siyasal-kültürel karakteri haline gelmiş olan üç temel özelliklerine vurgu yaparak cevaplamaya çalışmıştır (Ergil, 1995, s. 163-164):

a. İsviçre federal bir devlet olarak federalizm ilkesine göre yönetilmektedir. Ancak federalizmin temelinde azınlıkların korunması düşüncesi yer almamaktadır. Yaklaşık olarak 150 yıl önce 26 adet bağımsız kanton kendi aralarında "Bund" adı verilen birlik kurmuşlardır. Ancak bu birlik kapsamında hiçbir kanton kendi bağımsızlığından ve egemenliğinden taviz vermemiştir. Yalnızca ortak yönetime vurgu yapmak amacıyla kendi ellerinde tutukları bir takım yönetsel hakları üst yapılanmaya devretmişlerdir.

b. İsviçre'nin bir diğer önemli özelliği çokdilli olmasıdır. İsviçre'de çokdillilik bir "kültür politikası" olarak benimsenmiştir. Kural olarak tüm yasal metinler, yürürlüğe girebilmeleri için, resmi dil olarak benimsenen Almanca, Fransızca, İtalyanca ve 
Romansça'ya çevrilmektedir. İsviçre'de dil özgürlüğü Federal Mahkeme tarafından güvence altına alınmıştır. Bunun anlamı ise İsviçre'de vatandaşların ister özel hayatlarında isterse de kamu kurumlarında istedikleri dili kullanabilme özgürlüğüne sahip olmalarıdır. Fransızca ve İtalyanca konuşulan kantonlarda bu iki resmi dil hem okullarda eğitim dili olarak hem de kamu kurumlarında resmi dil olarak kullanılmaktadır.

c. Üçüncü ve son özellik ise "olumlu ayrımcllık ilkesi”dir. Bu ilke belirli durumlarda azınlıkların aşırı temsil edilmesi şeklinde kullanılmaktadır. Bir diğer anlamlandırma ile temsil konusunda azınlıkta kalan grupların kayırılması şeklinde uygulanmaktadır. Bu ilke ile azınlıkta kalan grupların eşit vatandaşlık haklarına kavuşturulabilmesi için olumlu ve pozitif ayrımcilık uygulamalarına tabi tutulmaları hedeflenmektedir. Bunun için de azınlıkların temsil edilebilirliklerinin arttırılması öngörülmektedir. İsviçre bu hedefe yasama, yürütme, yargı ve eğitim dili alanlarında ortak bir paydada buluşmak amacıyla yasal-kurumsal dayanak oluşturarak ulaşmaya çalışmıştır.

Toplumsal farklılıkların (etnik, dilsel, ırksal, dinsel) kültür başlı̆̆ı altında incelenmesi, farklılıkların yönetimi bağlamında ulus bilinci ve kimliği oluşturma açısından önem taşımaktadır. Ancak bu gibi bir bilinç oluşturma aşamasında yerel değerleri yok saymak ve göçmen grupları dışlamak ulaşılması istenen hedefi uzaklaştırabilecektir (Triandafyllidou, 2014, s. 42). Çünkü bireysel veya toplumsal farklılıkları yönetebilmek için ortaya çıkan değişken unsurların kaynağına ulaşmak gerekmektedir. Bir diğer anlatım ile ortaya çıkan farklılıkların sebebini belirleyebilmek, karşılıklı olarak çözümsel noktalara temas etmek ve ortak bir noktada buluşabilmek için uyun bir "yöntemin” bulunması ve farklılıklardan kaynaklanan, bu sebepten dolayı, sorun gibi görünen konuların "karara bağlanması" zorunluluk taşımaktadır (Nozick, 2006, s. 141).

\section{Toplumsal Farklılıkların Yönetimi Alanında Etkin Bir Araç: Sivil Toplum Kuruluşları}

Sivil toplum kavramının kökeninde toplumsal birlikteliğin nasıl olması gerektiği sorgusunun kurgusuna rastlamak mümkündür. 18. Yüzyıl'da, sivil toplum bir arada yaşamanın anahtar kavramı olarak gündeme gelmiştir. Bu bağlamda, sivil toplum, toplulukların kendi farklılıkları içerisinde sınırlı bir alanda yaşarken, diğerleri ile bütünleşmek için kullanılabilecek "analitik bir araç” olarak kabul görmeye başlamıştır (Sarıbay, 2014, s. 52).

Sivil toplum, devlet organizasyonunun dışında konumlanmış bir yapılanmadır. Bu yapılanma siyaset, kültür, çevre ve ekonomi ana başlıkları dâhilinde kurgulanmış konular üzerinde çalışmaktadır. $\mathrm{Bu}$ açıdan değerlendirildiği takdirde sivil toplum sosyal sorumluluklar ile toplumsal faaliyetleri yerine getiren ve gönüllük esası kapsamında örgütlenmiş kuruluşlar biçiminde tanımlanabilmektedir. Bununla birlikte, sivil toplum bireylerin müşterek kararları ve istekleriyle oluşturdukları ortak bir yaşam alanının sınırlarını da belirlemektedir (Talas, 2011, s. 388-389).

Sivil toplum kuruluşları toplumsal sorunların çözümlenmesinde hükümet dışında yer alarak sürece katkı yapmaya çalışan gönüllü halk topluluklarıdır. Sivil toplum kuruluşlarının temel 
amacı siyasal iktidarı ele geçirmek değil, talep edilen isteklerin gerçekleştirilmesini sağlamak amacıyla karar alma aşamasına katılmaktır. Sivil toplum devlet müdahalesinin olmadığı ve gönüllü kuruluşların toplumun ortak değerlerini siyasi iktidara benimsetmek için kullandığı özerk bir alandır. Bu özerk alanın devlet müdahalesi ve otoritesi dışında kalmasından dolayı devlet ile sivil toplum ilişkilerini düzenleyecek siyasi bir kültüre ihtiyaç duyulmaktadır (Emini, 2013, s. 44-45).

Sivil toplum örgütlü halk toplulukları olarak sosyal hayatın bütün alanına yayılmış durumdadır. $\mathrm{Bu}$ sebepten dolayı toplumun tüm kesimleri yaşanan toplumsal ve siyasal olaylardan doğrudan bilgi sahibi olabilmekte ve sosyolojik analizlerde bulunabilmektedirler. Aynı zamanda sivil toplum kuruluşları elde ettikleri güç ve toplumsal destek ile siyasi iktidarı değiştirebilecek ve yerine yenisini getirebilecek ölçüde baskı unsuru olarak da faaliyet gösterebilmektedir (Talas, 2011, s. 388).

Sivil toplum kavramı liberal düşüncenin öğretileri ile bütünlük taşımaktadır. Çünkü liberal öğreti, devlet yönetiminde sivil düşüncenin veya sivil yönetim şeklinin olması gerekliliği üzerine yoğunlaşırken, sivil toplum da kurgusal çerçevede aynı hedef doğrultusunda hareket etmektedir. $\mathrm{Bu}$ hareket biçiminin temel kavramları arasında yer alan "toplumsal farklılaşma" sivil bir öğretinin gerekliliğini oluşturmaktadır (Çaha, 2005, s. 17).

Devlet dışında yer alarak toplumsal faaliyetlerde bulunan sivil toplum kuruluşlarının ilgileri genel anlamda toplumsal gelişme, insani çalışmalar, çevre ve insan hakları üzerine yoğunlaşmaktadır. Her sivil toplum kuruluşu, kendilerine hedef olarak belirledikleri konu başlıklarına ulaşabilmek için alanlarında uzmanlaşma yöntemini belirlemişlerdir. Bu sayede sadece belirli alanlardaki politikalar üzerinde toplumsal farklılık yaratmaya çalışmaktadırlar (Willets, 2011, s. 8).

Devlet dışında sivil örgütlenmenin hedefinde birliktelik, dostluk, birlikte bir şeyler paylaşma ve başarma arzusu ve toplu hareket etme içgüdüsü yer almaktadır. Bireylerin tek başlarına yapamadıkları faaliyetleri örgütlenmiş sivil toplum kuruluşları kapsamında ve desteğinde yapmak oldukça kolay bir hale gelebilmektedir. Sivil toplum kuruluşlarının hedefinde maddi kazanç elde edebilme isteği yerine, toplumsal dayanışma içerisinde belirli amaçları gerçekleştirme arzusu yer almaktadır (Talas, 2011, s. 389).

Toplum içerisinde sivil toplum kuruluşlarının ortaya çıkmasının ve gelişmesinin temel koşulları bulunmaktadır. Bu koşullar beş temel başlık kapsamında sıralanabilmektedir: Toplum yapısında gözlemlenen etnik, kültürel, dinsel, ideolojik ve ekonomik farklılaşma; toplumsal düzeyde hükümet dışında kalabilme; farklılaşmış alan ve konularda politika üretebilecek toplumsal tabanın oluşturulması; devletin vesayetinden uzak biçimde toplumsal kurumların kendi politikalarını belirleyebilme özgürlügüne sahip olmaları ve baskı unsuru olarak görev yapmalarıdır (Emini, 2013, s. 389).

Sivil toplum kuruluşları toplum içerisinde var olan farklılıkları kalıcı bir biçimde birbirine bağlayarak bütünleştirici bir görev üstlenmektedirler. Bu görevi yerine getirebilmek ve 
farklılıklardan bir değer elde edebilmek amacıyla devlet ve yerel yönetimler ile işbirliği içerisinde çalışmaktadırlar. Sivil toplum kuruluşlarının varlığında toplum içerisinde kendisini ifade edemeyen veya sosyo-ekonomik olarak gelişme gösteremeyen grupların temsil edilebilmesi amacıyla kendilerine söz hakkı tanınmaktadır (Okutan, 2008, s. 99). Bu noktadaki temel hedef veya ince nokta farklılıkların ayrıştırmacı bir olumsuzluk olarak değil, bütünleştirici bir değer olarak görülmesidir (Demir, 2018, s. 257; Tatar, 2012, s. 93).

Sivil toplum idealinin demokrasi kültüründen beslendiğini ifade etmek gerekmektedir. Demokrasi kültürünün gelişmiş olduğu bir ülkede farklılıklara saygı gösterilmesini beklemek olasılıklar içerisinde üst sıralarda yer almaktadır. Aynı zamanda etkin sivil toplum faaliyetleri sonucunda toplumda birey hakları koruma altına alınmış olmaktadır. Bireyler yaşamış oldukları toplum içerisinde kendi farklılıklarının farkına varmakta, bu farklılıklarını koruma ve sürdürme içgüdüsü ile hareket etmekte ve kişisel haklarını savunmayı öğrenmektedirler (Betil, 2010, s. 22). Çünkü sivil toplum bireylerin ortak hedefler etrafında birleşebildiği özgürlükçü bir alan yaratmaktadır. Bu alan ahlaki ve siyasi değerler ile biçimlendirilerek bireyin toplumsal ruh kazanması için aracı bir görev üstlenmektedir. Toplumsal ruhun bireye kazandırabileceği değer ise kendisi hakkında karar alınırken karar sürecinde yer alması ve gerektiği durumda karara itiraz edebilmesi yeterliliğidir (Demir, 2014, s. 63).

$\mathrm{Bu}$ yeterlilik bireye "şiddetsiz toplumsal denetim" hakkı tanımaktadır (Rupnik, 2004, s. 307). Çünkü şiddet içeren toplumsal tepkiler bir başkasını yaralamak veya öldürmek biçiminde kendisini göstermektedir. Oysaki şiddetsiz toplum düzeni için kurgulanacak sivil bir sistemde "geniş toplumsal gruplar" ortak değerler etrafında toplanabilmektedir (Elias, 2004, s. 199). Bu sonuca ulaşmak için ise devletin yönetim sisteminin sivil toplum ekseninde yeniden kurgulanması gerekmektedir (Demir, 2018, s. 249).

Sivil toplumun güçlü olduğu ülkelerde yaşanan gelişmelerin odak noktasında merkezi hükümet yer almamakta, ortak bir yönetim modeli kapsamında sivil toplumun mutlak bir ağırlığının olduğu gözlemlenmektedir. Sivil toplumun desteğinin alındığı bir yönetim sistemi içerisinde toplumsal duyarlılıkta artış gözlemlenmekte ve böylece farklılıklara saygı gösterilmektedir (Betil, 2010, s. 22). Çünkü sivil toplum, devlet ile toplum arasında dengeleyici bir görev üstlenmektedir. $\mathrm{Bu}$ sayede farklılıklardan kaynaklanan anlaşmazlıklar, toplumsal huzursuzluklar ve çatışmacı yaklaşımlar en aza indirilmeye çalışılmaktadır (Demir, 2014, s. 64).

\section{Sonuç}

Bir toplum içerisinde hemen her konuda farklı düşüncelere sahip insanlar bulunabilmektedir. Bu farklı düşünceler toplumun çok kültürlülüğünü ve dolayısıyla da farklılı̆̆ını oluşturan ve toplumu pasif bir unsur olmaktan kurtararak etken bir özne olmak için tetikleyen en temel araçtır. Farklılıklarının farkına varamayan veya öteleyen, yabancılaştıran, yok sayan ve ihmal eden toplumlar kendi geleceklerini görünmez bir kafes içerisine hapsetmektedirler. Dolayısıyla bir toplumun tek tip olması kendi yanında sıradanlığı ve eylemsizliği getirmektedir. Toplumsal huzurun sağlanmasında devletin ve sivil toplum kuruluşlarının ortak biçimde çalışması gerekmektedir. Bu noktada her ikisine de ihtiyaç duyulmaktadır. Devlet, sivil toplum 
kuruluşlarının hareket alanlarını genişleterek ve toplumsal uzlaşının sağlanması adına adımlar atarak toplumsal bütünlüğü sağlayabilecek yeterliliğe sahiptir. Sivil toplum kuruluşları ise bireylerin örgütlenmiş şekli olarak toplumu etken bir özne haline getirebilmek adına bireylere yönetimde söz hakkı tanınması için faaliyetlerde bulunmaktadırlar. Bu noktadaki temel amaç devleti ve toplumu bir araya getirerek toplumun farklılıklarını aynı ortamda eritmeden ve farklılıkları yok saymadan ortak bir çatı altında buluşturmaktır.

Farklılıkların bir ülkenin kültürel zenginliği olarak değerlendirildiği durumda yapılması gereken öncelikli işlem her farklılı̆̆ kendi özgül ağırlığı çerçevesinde olduğu gibi kabul ederek, özerk bir çerçevede bütünden uzaklaştırmadan yaşatılmasına olanak sağlamaktır. $\mathrm{Bu}$ amacı gerçekleştirebilmek için de herşeyden önce devletin yönetim sistemi içerisinde sivil toplum kuruluşlarının söz haklarını çoğaltabilmek amacıyla devlet yönetimi ile sivil toplum birlikteliğine yer vermek önem taşımaktadır.

Bir ülkede farklılıkların yönetilebilmesi için bütünden parçaya doğru bir seyir izleyerek, her parçanın kendi yaşam alanı içerisinde kendi farklılığını koruyabileceği bir zemin yaratabilmek değerlerin korunabilmesi adına önem taşımaktadır. Bu hedefi gerçekleştirebilmek için de farklılıkların bütün içerisinde etnik, kültürel ve dinsel konularda özerk düşler kurmasına olanak tanınması gerekmektedir. Böylece farklı parçaların birleşerek bütüne doğru ilerlediği veya bütünü oluşturduğu bir düzen kurgulanmış olacaktır. Bu düzen içerisinde kurgulanan özerk unsurların niteliklerinin gerçek anlamda bağımsız veya bütünden ayrılan bir oluşum kapsamında yorumlanmaması ulaşılmaya çalışılan hedefin kolay biçimde görülebilirliğinin sağlanması adına önem taşımaktadır.

Farklılıkların kültür üzerinde yoğunlaşması ve kültürel değerlerin değişkenlik göstermesi farklılıklara sebep olabilecek etkenler arasında sayılmalarına rağmen, kültür olarak kavramlaştırılan olgunun temelinde bireylerin karşılıklı etkileşimi sonucunda ortaya çıkan değişkenlerin taşıdığı değer(ler) yer almaktadır.

Farklılıkların yönetilmesi ideali bulmaca içerisinde yer alan her harfin büyük bir önem taşıdığı düşüncesine dayanmaktadır. Çünkü bir bulmacayı çözme aşamasında ihtiyaç duyulan her harfin olması gerektiği boşluğa yerleştirilemediği takdirde, harf yığınlarından oluşan anlamsız kelimeler ortaya çıkmakta ve bütün bir kelimeye ulaşmak zorlaşmaktadır. Kelimelerin doğru sıralanışı bulunamadığı durumda ise bulmacanın bütününü çözmek imkânsız bir duruma gelmektedir. Çünkü her kelime bir başka kelime ile bağlantılı durumdadır. Harf boşlukları doğru bir biçimde doldurulamadığı durumda zincirmele bir hata tepkimesi ortaya çıkmakta ve hem kelime oluşturulamamakta hem de bulmacanın bütününe ulaşma konusunda büyük bir engel ortaya çıkmaktadır.

Farklılıkların yönetimi farklılıkları yok etmek değil, bir arada tutabilmek süreci ve yeteneğidir. Toplumsal farklılıklar genel anlamda bir toplum içerisinde kendisine yaşam alanı bulan çeşitli kültür, millet, ırk, etnik köken, dini inanış, adet, gelenek, cinsiyet, ten rengi, konuşulan dil ve siyasi görüş kapsamında şekillenmektedir. Bu farklı unsurlar bir toplumun bünyesinde herhangi 
bir soruna sebep olmadan birlik ve bütünlük içerisinde kendilerine yer bulabiliyorlar ise o toplumda toplumsal huzurun varlığından söz edilebilmektedir. Bunu sağlamak için de yalnızca devlet veya sivil toplum kuruluşlarının tek yanlı çabası yetmemektedir. Bu konuda siyaseti sivilleştirmek ve toplumun her katmanına yaymak gerekmektedir. Bu sayede bireylerin içerisinde yaşamış oldukları toplumun kendilerini kucaklayan bir yönetim ile bütünleşmesi sağlanabilecektir.

\section{Kaynakça}

Albanese, C. L. (2012). America: Religions and Religion. 5th Edition, Boston, USA: WADSWORTH CENGAGE Learning.

Arıcan, M. K. (2011). Felsefî ve Teolojik Bir Problem Olarak Dinî Çeşitlilik. Cumhuriyet Üniversitesi İlahiyat Fakültesi Dergisi, 15 (1), 71-98.

Barth, F. (1998). Introduction, Fredrik Barth (Ed.). Ethnic Groups and Boundaries The Social Organization of Culture Difference içinde (pp. 9-39). Long Grove, Illinois: Waveland, Inc..

Beeghley, L. (2016). The Structure of Social Stratification in the United States, New York: Routledge Taylor \& Francis Group.

Betil, İ. (2010). Sivil Toplum, Sosyal Sermaye, Sosyal Girişimcilik. Girişimcilik ve Kalkınma Dergisi, 5 (1), 21-25.

Bottero, W. (2005). Stratification: Social Division and Inequality. Great Britain: Routledge Taylor \& Francis Group.

Brown, M. E. (1993). Causes and Implications of Ethnic Conflict. Michael E. Brown (Ed.). Ethnic Conflict and International Security içinde (pp. 3-26). Princeton, New Jersey: Princeton University.

Budrina, I. (2019). Multiculturalism: United in Diversity: A Romanian Perspective. Romania: CORESI Publishing House.

Canatan, K. (2009). Avrupa Toplumlarında Çokkültürcülük: Sosyolojik Bir Yaklaşım. Uluslararası Sosyal Araştırmalar Dergisi, 2 (6), 80-97.

Çaha, Ö. (2005). Sivil Toplum Üstüne. Lütfi Sunar (Yay. Haz.), Sivil Toplum ve Demokrasi içinde (s. 9-22). İstanbul: Kaknüs.

Demir, K. A. (2018). Toplumsal Uzlaşıda Devlet Yönetimi ile Toplum Arasındaki Fren-Denge Unsuru: Sivil Toplum Yönetimi Üzerine Bir Değerlendirme, Çankırı Karatekin Üniversitesi İktisadi ve İdari Bilimler Fakültesi Dergisi, 8 (1), 247-271.

Demir, K. A. (2014). Merkeziyetçi Yönetim Kıskacında Sivil Toplum Çıkmazı. Dumlupınar Üniversitesi Sosyal Bilimler Dergisi, 41, 61-70.

Desmet, K., Ortuño-Ortín, I. \& Wacziarg, R. (2017). Culture, Ethnicity and Diversity. UCLA Anderson Center for Global Management, March, 1-37. 
Dhawan, M.L. (2005). Philosophy of Education. Delhi, India: Isha Books.

Düzgit, S. A. (2014). Avrupa'nın Kültürel İnşası: Alman Siyasi Söyleminde Türkiye Tartışmaları. Ayhan Kaya (Der.), Farklılıkların Birlikteliği Türkiye ve Avrupa'da Birarada Yaşama Tartışmaları içinde (s. 72-91), Hiperlink Yayınları: 72, Ankara: Hiperlink.

Ekici, Ö. K. (2012). Dillerin Çeşitliliği. TÜBİTAK Bilim ve Teknik Dergisi, 46-51.

Elias, N. (2004). Şiddet ve Medeniyet: Fiziki Şiddet Üzerindeki Devlet Tekeli ve Bunun İhlali. John Keane (Der.), Ahmet Çiğdem-Levent Köker (Çev.), Sivil Toplum ve Devlet içinde (s. 197-221), Ankara: Yedi Kita.

Emini, F. T. (2013). Sivil Toplum Kuruluşlarının Politika Belirleme Sürecindeki Rolü: TÜSİAD Örneği. Dumlupınar Üniversitesi Sosyal Bilimler Dergisi, 36, 43-56.

Ergil, D. (1995). Çokkültürlülük ve Çokdillilik. Ankara Üniversitesi Siyasal Bilgiler Fakültesi Dergisi, 50 (3), 159-165.

Erincik, S. (2011). Kimlik ve Çokkültürcülük Sorunu. Ankara Üniversitesi İlahiyat Fakültesi Dergisi, 52 (2), 219-241.

Fettahlıoğlu, Ö. O. \& İnce, M. (2013). Çalışma Yaşamında Farklıkların Yönetimi Uygulamalarının İş Doyumuna Etkisi: Tekstil Sektöründe Alan Araştırması. Kahramanmaraş Sütçü İmam Üniversitesi İktisadi İdari Bilimler Fakültesi Dergisi, 3 (1), 77 87.

Garbier, Y. T. (1952). Social Differentiation in Co-operative Communities. The British Journal of Sociology, 3 (4), 339-357.

Gianfranco, P. (2012). Modern Devletin Gelişimi Sosyaolojik Bir Yaklaşım. 6. Baskı, Şule Kut ve Binnaz Toprak (Çev.), İstanbul: İstanbul Bilgi Üniversitesi.

Guo, Y. (2016). Introduction: class and strafication in the People's Republic China, Handbook on Class and Social Stratification in China içinde (pp. 1-20). UK: Edward Elgar.

Güleş, H. (2012). Örgütlerde Farklılıkların Yönetimi: Okullara İlişkin Bazı Çıkarımlar. The Journal of Academic Social Science Studies, 5 (8), 615-628. (December 2012, Publication of Association Esprit, Société et Rencontre Strasbourg/FRANCE)

Gündüz, Z. Y. (2006). Avrupa Birliği’nin Dil Sorunu. Ankara Avrupa Çalışmaları Dergisi, 5 (3), 199-217.

Hayek, F. A. v. (2014). Kölelik Yolu (The Road to Serfdom). Turhan Feyzioğlu, Yıldıray Arsan, Atilla Yayla (Çev.), Ankara: Liberte.

Helvacıoğlu, N. \& Özutku, H. (2010). Kültürel Farklılıkların Yönetiminde İnsan Kaynakları Stratejilerinin Rolü: IKEA Örneği. Yönetim Bilimleri Dergisi, 8 (1), 194-216.

Horsti, K. (2011). Celebrating Multiculturalism: European Multicultural Media Initiatives as Anti-Racist Practices. Mark D. Alleyne (Ed.). Anti-Racism and Multiculturalism: Studies in International Communication içinde (pp. 153-168). New Brunswick, New Jersey: Transaction. 
Juteau, D. (2003). Introducing Social Differentiation, Danielle Juteau (Ed.), Social Differentiation: Patterns and Processes içinde (pp. 3-24). Canada: University of Toronto Press Incorporated.

Karaca, M. (2012). Farklılaşma, Bütünleşme ve Birlikte Yaşama Üzerine. Dicle Üniversitesi Ziya Gökalp Eğitim Fakültesi Dergisi, 18, 226-238.

Kaya, A. (2014). Giriş: Ötekini Anlamak Mümkün mü?. Ayhan Kaya (Der.). Farklılıkların Birlikteliği Türkiye ve Avrupa'da Birarada Yaşama Tartışmaları içinde (s. 11-37). Hiperlink Yayınları: 72, Ankara: Hiperlink.

Kymlicka, W. (1995). Multicultural Citizenship: A Liberal Theory of Minority Rights. Oxford: Clarendon.

Kymlicka, W. \& Norman, W. (2003). Citizenship in Culturally Diverse Societies: Issues, Contexts, Concepts. Will Kymlicka \& Wayne Norman (Eds.). Citizenship in Diverse Societies içinde (s. 1-41), New York: Oxford University.

Lake, D. A. \& Rothchild, D. S. (1998). Spreading Fear: The Genesis of Transnational Ethnic Conflict, The International Spread Of Ethnic Conflict: Fear, Diffusion, And Escalation içinde (pp. 3-32). Princeton, New Jersey: Princeton University.

Loden, M. \& Rosener, J. B. (1991). Workforce America! Managing Employee Diversity As A Vital Resource. Homewood, Illinois: Business One Irwin.

Mark, N. (1998). Beyond Individual Differences: Social Differentiation from First Principles. American Sociological Review, 63 (3), 309-330.

Mazur, B. (2010). Cultural Diversity in Organisational Theory and Practice. Journal of Intercultural Management, 2 (2), 5-15.

Nişancı, Ş. \& Işık, C. (2012). Etnisite Kavramının Siyasal Tercihler Üzerine Etkisi: Kars İli Kağızman İlçesi Üzerine Bir Çalışma. II. Bölgesel Sorunlar ve Türkiye Sempozyumu 1-2 Ekim 2012, 109-133.

Nozick, R. (2006). Anarşi, Devlet ve Ütopya. Alişan Oktay (Çev.), İstanbul: İstanbul Bilgi Üniversitesi.

Odabaş, Z. Y. (2018). Toplumsal Değişme Sürecinde Kentleşme ve Nüfus. Davranış Bilimleri I. Ayşe Çiğdem Kırel Zerrin Sungur Taşdemir (Ed.), Eskişehir: Anadolu Üniversitesi Yayını No: 2709, Açıköğretim Fakültesi Yayını No: 1672, s. 171-195.

Okutan, E. (2008). Yerel Yönetimler ve Sivil Toplum Örgütlerinin Gelişmiş İşbirliği: İngiltere Örneği. Sayıştay Dergisi, Ekim-Aralık, 71, 91-108.

Pless, N. \& Maak, T. (2004). Building an Inclusive Diversity Culture: Principles, Processes and Practice. Journal of Business Ethics, October, 54 (2), 129-147.

Rawls, J. (2005). A Theory of Justice. USA: Harvard University Press.

Rupnik, J. (2004). Totalitarizmin Yeniden Değerlendirilmesi. John Keane (Der.), Ahmet Çiğdem (Çev.). Sivil Toplum ve Devlet içinde (s. 291-318), Ankara: Yedi Kita. 
Saha, L. J. (2007). Education and Active Citizenship: Prospects and Issues. Joseph Zajda (Ed.). Education and Society içinde (s. 13-23), Australia: James Nicholas Publishers.

Sarıbay, A. Y. (2014). Postmodernite Sivil Toplum ve İslam. Bursa: Sentez.

Simon, H. A., Smithburg, D. W. \& Thompson, V. A. (1985). Kamu Yönetimi, Cemal Mihçığlu (Çev.), Ankara: Ankara Üniversitesi Siyasal Bilgiler Fakültesi.

Smith, A. D. (1993). The Ethnic Sources of Nationalism. Michael E. Brown (Ed.). Ethnic Conflict and International Security içinde (pp. 27-41). Princeton, New Jersey: Princeton University.

Sosyal, A. \& Yalçın, Y. (2013). Örgütlerde Farklılıkların Yönetiminde Yeni Bir Yaklaşım: Müzakereci Kişilik. Kahramanmaraş Sütçü İmam Üniversitesi İktisadi İdari Bilimler Fakültesi Dergisi, 3 (1), 27-41.

Spencer-Oatey, H. (2012). What is culture? A compilation of Quotations, GlobalPAD Core Concepts.https://www2.warwick.ac.uk/fac/soc/al/globalpad/openhouse/interculturalskills/ global_pad_-_what_is_culture.pdf, (Erişim Tarihi: 21.07.2018).

Sürgevil, O. (2008). Farklılık Kavramına ve Farklılıkların Yönetimine Temel Oluşturan SosyoPsikolojik Kuramlar ve Yaklaşımlar. Balıkesir Üniversitesi Sosyal Bilimler Enstitüsü Dergisi, 11 (20), 111-124.

Talas, M. (2011). Sivil Toplum Kuruluşları ve Türkiye Perspektifi. TÜBAR (Türklük Bilimi Araştırmaları) Dergisi, 29, 387-401.

Tatar, H. C. (2012). Batının Kimlik İnşasında Ötekinin Yeri, Karadeniz (Black Sea-Черное Mоре) Sosyal Bilimler Dergisi, 14, 91-102.

Triandafyllidou, A. (2014). Kültürel Çeşitlilik, Çoğul Milliyetçilik ve Avrupa Kimliği. Ayhan Kaya (Der.), Farklılıkların Birlikteliği Türkiye ve Avrupa'da Birarada Yaşama Tartışmaları içinde (s. 41-56), Hiperlink Yayınları: 72, Ankara: Hiperlink.

Türk Dil Kurumu Sözlügü, http://www.tdk.gov.tr/index.php?option=com_bts\&arama=kelime\&guid=TDK.GTS.596e 0dd1e2f575.74617348, (Erişim Tarihi: 01.07.2018).

United States Government Accountability Office (2005). Diversity Management ExpertIdentified Leading Practices and Agency Examples, Report to the Ranking Minority Member, Committee on Homeland Security and Governmental Affairs, U.S. Senate, January 2005, 1-47, http://www.gao.gov/assets/250/245069.pdf (Erişim Tarihi: 06.07.2018).

UNESCO Kültürel Çeşitlilik Evrensel Bildirgesi, 2 Kasım 2001, http://www.unesco.org.tr/dokumanlar/kulturel_ifadelerin_cesitliligi/EVRENSEL_B\%C4 \%B0LD\%C4\%B0RGE.pdf, (Erişim Tarihi: 15.07.2018).

Vatandaş, C. (2001). Çokkültürlü Yapıda Ulusal/Etnik Kimlikler (Kanada Örneği). Afyon Kocatepe Üniversitesi Sosyal Bilimler Dergisi, 3 (2), 101-117.

Yayla, A. (2000). Özgürlük Yolu Hayek'in Sosyal Teorisi. Ankara: Liberte. 
Yaylacı, F. G. (2017). Süper-Çeşitlilik Çağında Çokkültürcülük. Hitit Üniversitesi Sosyal Bilimler Enstitüsü Dergisi, 1, 345-364.

Washington, D. (2008). The Concept of Diversity. Durham: Washington \& Company.

Willets, P. (2011). Non-Governmental Organizations in World Politics The Construction of Global Governance (Global Institutions). London and New York: Routledge Taylor \& Francis Group. 